\title{
Ozone treatment on cucumber and tomato during simulated retail storage
}

\author{
MAI SAO DAM ${ }^{1}$, VUONG DUC NGUYEN ${ }^{1}$, TAMÁS ZSOM ${ }^{2}$, \\ LIEN LE PHUONG NGUYEN ${ }^{2 *}$ (1) and GÉZA HITKA ${ }^{2}$
}

\footnotetext{
${ }^{1}$ Institute of Biotechnology and Food Technology, Industrial University of Ho Chi Minh City, Ho Chi Minh, 700000, Vietnam

${ }^{2}$ Institute of Food Science and Technology, Hungarian University of Agriculture and Life Sciences, 1118, Budapest, Hungary
}

\section{CONFERENCE FULL PAPER}

Received: May 5, 2021 • Accepted: July 30, 2021

Published online: August 30, 2021

(C) 2021 The Author(s)

\section{ABSTRACT}

The effect of storage temperature and ozone treatment on the post-harvest quality of cucumber and tomato was investigated. Cucumber and tomato were stored together with or without gaseous ozone treatment at $20^{\circ} \mathrm{C}$ and $14^{\circ} \mathrm{C}$ for 16 days. Firmness, color, weight loss, DA index and decay percentage of samples were evaluated during storage period. The results showed that the combination of ozone treatment and cold storage could maintain the quality of these horticultural products and decreased the decay incidence. Additionally, this combination also reduced the weight loss of samples during storage. Furthermore, ozone treatment maintained the green skin color of cucumber. No sign of chilling injury occurred during storage at $14^{\circ} \mathrm{C}$. Commodities stored with approximately $0.1 \mathrm{ppm}$ gaseous ozone at $14^{\circ} \mathrm{C}$ retained the firmness compared to other treatments until the end of the experiment. This study suggests a promising use of gaseous ozone treatment in storage chamber where ethylene-producing and ethylene-sensitive vegetables are stored together.

\section{KEYWORDS}

post-harvest, ethylene-sensitive, acoustic firmness, vegetables

\footnotetext{
*Corresponding author. E-mail: nguyen.le.phuong.lien@uni-mate.hu
} 


\section{INTRODUCTION}

Fruits and vegetables are essential foods for daily healthy diet. The postharvest ripening results in changing the quality of products including nutrition and appearance (Liu, 2014). Thus, maintaining quality of fruits and vegetables to meet consumers' demand is necessary.

Most of horticultural produce are not consumed immediately after harvest. In supply chain, ethylene-sensitive and ethylene-producing commodities are usually stored together. The high ethylene concentration in the storage room accelerates the ripening and senescence that cause postharvest loss of fresh fruits and vegetables (Liu, 2014). Therefore, to extend the shelf-life of ethylene-sensitive vegetables, removing the ethylene from storage room is necessary (Skog and Chu, 2001).

In order to prolong the postharvest life of horticultural products during retail storage, the development of new approaches is in demand. Cold storage is one of the most common applications in postharvest technology (Zhang et al., 2015).

Ozone is widely applied in postharvest management of horticultural commodities for two purposes including ethylene removal and sanitizing, particularly treatment pre-storage or during storage (Paulo et al., 2002). The efficacy of ozone in extending shelf-life and reducing microorganism of fresh products such as apple, pear, broccoli, cucumber and mushroom (Skog and Chu, 2001), as well as fresh melon (Nguyen et al., 2018) was reported.

Cucumber is one of the most important vegetables consumed as fresh or cooked, however, cucumber is highly sensitive to ethylene (Skog and Chu, 2001). Tomato is a climacteric and medium ethylene producing product (Watkins and Nock, 2012). In retail storage, cucumber and tomato are often stored with ethylene producing commodities that makes them deteriorate rapidly. Thus, this work was aimed to evaluate the effect of gaseous ozone treatment on tomato and cucumber during 16 days of storage at $20^{\circ} \mathrm{C}$ and $14{ }^{\circ} \mathrm{C}$.

\section{MATERIALS AND METHODS}

\section{Materials}

Cucumber (Cucumis sativus L.) and tomato (Solanum lycopersicum L.) were bought from a wholesale fruit and vegetable market. Samples were transported to the laboratory. Vegetables with uniformity of size and shape, and free from external damage were used for the experiment. Cucumber at green stage and tomato at red stage 5 of ripening according to tomato ripeness chart (Postharvest Technology Center, UC Davis) were selected. Samples were kept at $20^{\circ} \mathrm{C}$ or $14^{\circ} \mathrm{C}$ before ozone treatment.

Ozone was generated by an ozone generator (Neo.Tec XJ-100, China).

\section{Methods}

Experimental design. Samples were divided randomly into 4 groups, each group containing 15 cucumbers and 15 tomatoes. The weight of each piece was $81 \pm 3 \mathrm{~g}$ for cucumber and $122 \pm 3 \mathrm{~g}$ for tomato. Experiment was carried out with 4 storage conditions. Two groups were stored together at $20^{\circ} \mathrm{C}$ or $14^{\circ} \mathrm{C}$, $\mathrm{RH} 95 \%$ for 16 days with gaseous ozone treatment at approximately 
$0.1 \mathrm{ppm}$. The other two groups were kept at the same temperature without ozone treatment and served as control.

Measurements. The measurements were performed according to Baranyai et al. (2020), Nguyen et al. (2020a, 2020b) and Zsom et al. (2020).

Stiffness, surface color, weight loss, decay percentage and DA index were conducted at the initial time (day 0 ) and on the $4^{\text {th }}, 8^{\text {th }}, 12^{\text {th }}$ and $16^{\text {th }}$ day.

- Stiffness. Firmness of samples was estimated using the acoustic vibration method and expressed as the parameter Stiffness $\left(\mathrm{S}, \mathrm{g}^{2 / 3} \mathrm{~s}^{-2}\right)$. Stiffness of the samples was determined at 3 points on the exterior circumference of each fruit, using a tabletop acoustic firmness instrument of type AWETA AFS DTF V0.0.0.105 (AWETA, Nootdorp, The Netherlands) (Nguyen et al., 2020b).

- Surface color. Skin color of samples was measured with a portable Minolta Chroma Meter CR400 (Minolta Corporation, Osaka, Japan). Standard CIE L*, $\mathrm{a}^{*}$ and $\mathrm{b}^{*}$ color characteristics were determined at 3 points of each fruit. The hue angle value was calculated as arctangent of $\mathrm{b}^{*} / \mathrm{a}^{*}$ (Nguyen et al., 2020b).

- Weight loss. Weight loss was determined by weighing the samples at the beginning of the experiment and each interval with a balance (Sartorius, Germany). Results were expressed as percentage loss of initial readings according to Nguyen et al. (2020a).

- Decay percentage. Decay was evaluated as mold growth occurred on stem or surface of tomato and on the skin of cucumber. Decay percentage was calculated as the number of decayed samples divided by initial number of samples within a group multiplied by 100 (Baranyai et al., 2020).

- DA index. DA (or $\Delta \mathrm{A}$ ) index ${ }^{\circledR}$ of cucumber was measured by a FRM01-F type Vis/NIR DAmeter $^{\mathbb{B}}$ (Sintéleia s.r.l., Italy) at three points on cucumber skin to evaluate the changes of surface color related chlorophyll content during storage. The value of DA-index ${ }^{\circledR}$ varying from 0 to 5 is proportional to the amount of active chlorophyll existing in the sample (Zsom et al., 2020).

Statistical analysis. Data were collected and visualized on charts using Microsoft ${ }^{\circledR}$ Excel $^{\circledR}$ (version 16.45). All data were analyzed using analysis of variance (ANOVA) via SPSS version 11.0.1 (SPSS Inc, USA). Significant differences were determined using $P<0.05$. The results were reported as means with standard deviations.

\section{RESULTS AND DISCUSSION}

\section{Weight loss}

Figure 1 showed the results of weight loss during 16 days of storage. The control samples at $20^{\circ} \mathrm{C}$ were kept only till the $12^{\text {th }}$ day due to decay. The weight loss of vegetables increased at different rates over the storage period. Cold temperature decreased the weight loss of all samples. Vegetables stored at $14^{\circ} \mathrm{C}$ had lower values in weight loss compared to samples stored at $20^{\circ} \mathrm{C}$. The control sample kept at $20^{\circ} \mathrm{C}$ without ozone treatment had the highest values in weight loss for both cucumber and tomato. Gaseous ozone treatment was found to decrease the weight loss for cucumber. 

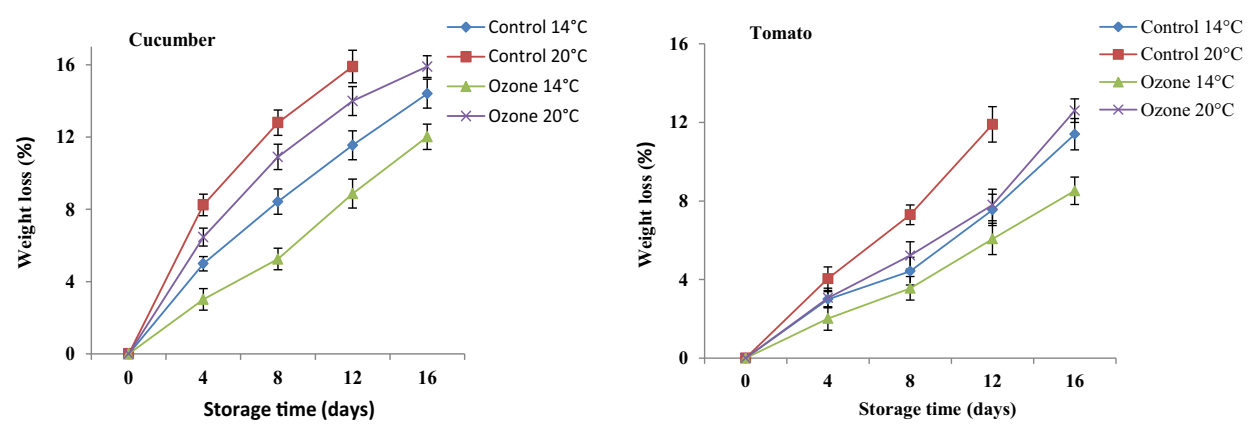

Fig. 1. Effect of storage conditions on weight loss of vegetables

The combination of storage at $14^{\circ} \mathrm{C}$ and gaseous ozone treatment was effective in reducing the weight loss of vegetables. The reason could be that cold temperature caused lower respiration rate and decelerated metabolism than higher one. Moreover, ozone treatment also had an effect in removing the ethylene in the storage chamber. This could delay the senescence of vegetables. There was no visible chilling injury on the skin of gaseous ozone treated vegetables over storage.

\section{Stiffness}

Changes of firmness were shown in Fig. 2. As can be observed, the firmness of vegetables decreased during 16 days of storage. Samples kept at $20^{\circ} \mathrm{C}$ without ozone were softer than others. Vegetables treated with gaseous ozone at $14^{\circ} \mathrm{C}$ had the highest values in firmness compared to other groups. Control samples at $20^{\circ} \mathrm{C}$ were stored until $12^{\text {th }}$ day due to decay.

Softening of horticultural products is due to biochemical processes during ripening (Ali et al., 2010). Cold storage or ozone treatment alone had less strong effect in delaying the ripening in comparison with ozone treatment at $14{ }^{\circ} \mathrm{C}$. The combination of cold temperature and ozone could delay the softening of commodities.
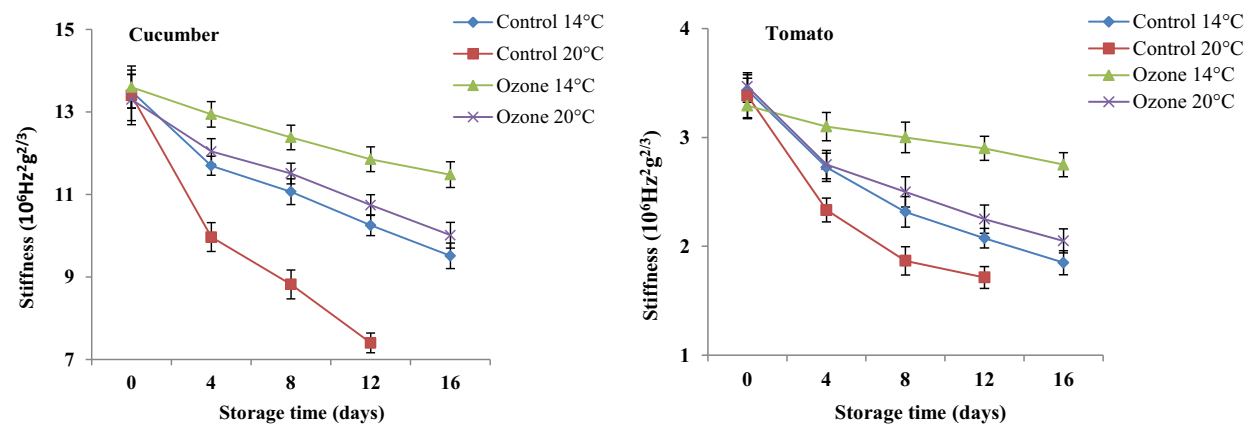

Fig. 2. Effect of storage conditions on stiffness of vegetables 


\section{Surface color}

Figure 3 showed the effect of treatments on skin color of vegetables. A significant change was observed in hue angle over storage period. Control samples at $20^{\circ} \mathrm{C}$ were stored until $12^{\text {th }}$ day due to decay. There was a dramatic decline in hue angle value for control cucumbers at $20^{\circ} \mathrm{C}$. The skin color of cucumber turned from green to yellow rapidly over storage at $20^{\circ} \mathrm{C}$, while the cucumbers treated with gaseous ozone at $14{ }^{\circ} \mathrm{C}$ were still green until the end of measurement. It was probably that cucumber is highly sensitive to ethylene, thus, the senescence of cucumber occurred promptly when the ethylene in the chamber increased (Al-Juhaimi et al., 2012). Ozone treatment slowed the color change of cucumber skin during the storage. It could be explained by the effectiveness of ozone in removing ethylene in the chamber, thus ethylene did not exert its action in ripening (Skog and $\mathrm{Chu}, 2001$ ).

The hue color of tomato decreased dramatically during storage. The control tomato at $20^{\circ} \mathrm{C}$ had the lowest value in hue angle. There was no significant difference in hue angle value between cold storage alone and cold storage with ozone treatment in the case of tomato.

\section{$\Delta \mathrm{A}$ index}

The results of $\Delta \mathrm{A}$ index of cucumber are shown in Fig. 4. The $\Delta \mathrm{A}$ index of all samples decreased over storage but at different rates. Control samples at $20^{\circ} \mathrm{C}$ were stored until $12^{\text {th }}$ day due to decay.

The decline of chlorophyll content relates to ripening during storage (Bron et al., 2004). The control cucumber at $20^{\circ} \mathrm{C}$ had the lowest value in $\Delta \mathrm{A}$ index. The results indicated a significant loss in chlorophyll content because the control cucumber at $20^{\circ} \mathrm{C}$ was at senescence stage. Cold storage with presence of ozone could delay the chlorophyll loss over storage.

\section{Decay percentage}

Figure 5 showed that there occurred les decay in the ozone treated groups than in the control groups. The fungal growth often occurred on the surface of cucumbers and on the stem of tomatoes. The result indicated that ozone had an effect in decreasing the rot percentage over storage due to the effectiveness of ozone treatment. Application of ozone in storage chamber could remove ethylene (Skog and Chu, 2001) and inhibit the growth of microbial pathogens on the fruit surface and in the chamber (Crisosto et al., 1993; Guzel-Seydim et al., 2004).
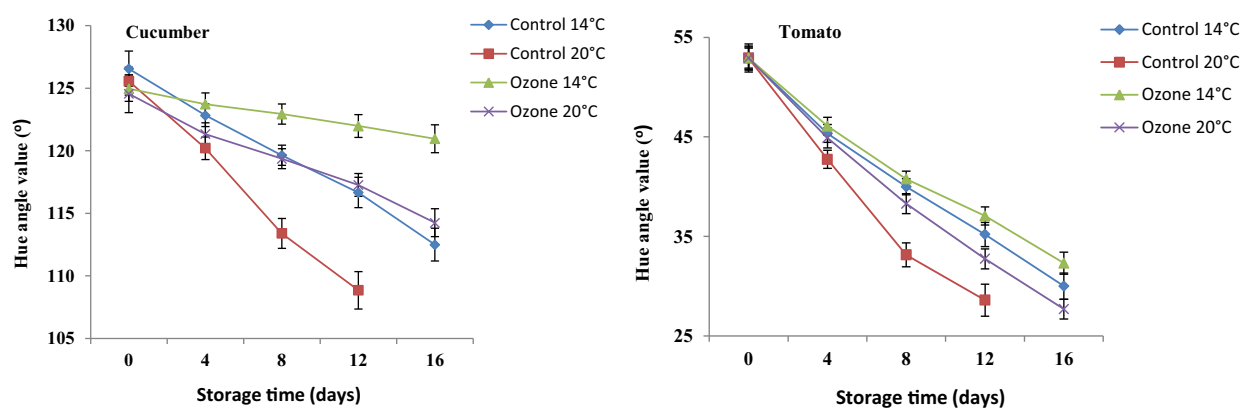

Fig. 3. Effect of storage conditions on surface color of vegetables 


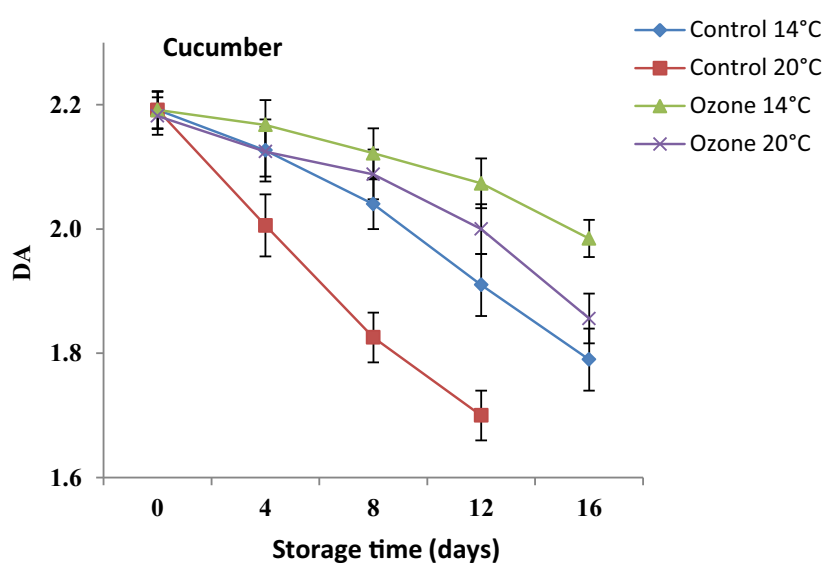

Fig. 4. Effect of storage conditions on DA index of cucumber
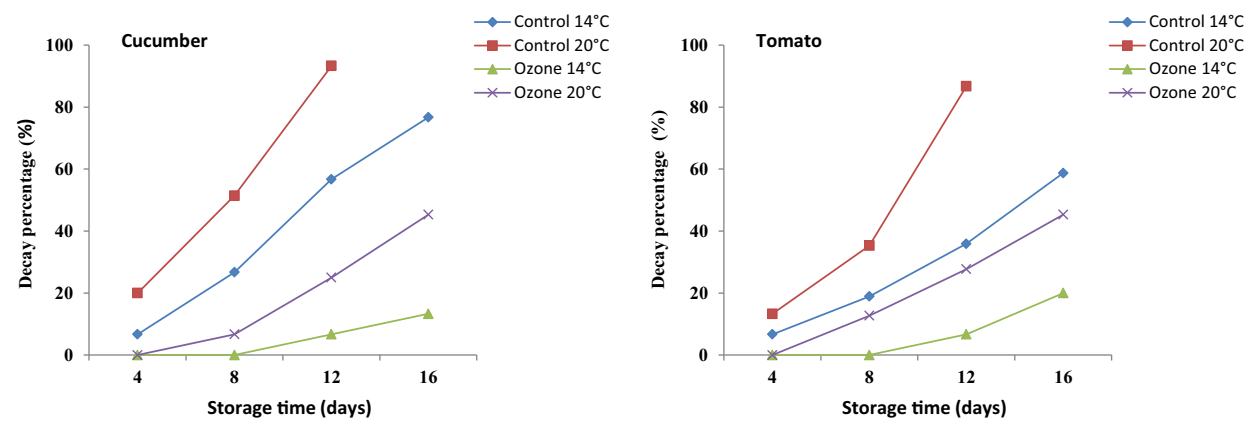

Fig. 5. Effect of storage conditions on decay percentage of vegetables

Control samples at $20^{\circ} \mathrm{C}$ were stored until $12^{\text {th }}$ day due to decay. The early sign of microbial development appeared on the $4^{\text {th }}$ day for control vegetables at $20^{\circ} \mathrm{C}$ and $14^{\circ} \mathrm{C}$, whereas the decay occurred on the $8^{\text {th }}$ day for the ozone treated group at $20^{\circ} \mathrm{C}$. At the same time samples treated with gaseous ozone at $14^{\circ} \mathrm{C}$ started decay at $12^{\text {th }}$ of storage. The susceptibility of cucumber and tomato also depended on temperature. When produce reached advancing ripening stage, the samples had more decay. This study found that the combination of gaseous ozone treatment and cold storage was effective in inhibiting the fungal growth for up to 12 days. The result of this work was in agreement with reports for peach and table grapes (Palou et al., 2002) and for date fruits (Habibi Najafi et al., 2009).

\section{CONCLUSION}

The presented work showed that gaseous ozone treatment during cold storage could maintain the quality of cucumber and tomato. Application of approximately $0.1 \mathrm{ppm}$ gaseous ozone 
retained the firmness, decreased the weight loss of vegetables over the storage period. Moreover, ozone slowed the yellowing of cucumber throughout 16 days of storage at $14{ }^{\circ} \mathrm{C}$. Additionally, decay percentage of vegetables also declined when they were stored in the presence of gaseous ozone. The results of this study found that gaseous ozone has potential application in postharvest treatment, particularly in distribution chain, when the ethylenesensitive horticultural products are stored together with ethylene-producing commodities. Further study about optimization of storage conditions for produces in retail chain should be carried out.

\section{ACKNOWLEDGMENTS}

The Project is supported by the European Union and co-financed by the European Social Fund (grant agreement no. EFOP-3.6.3-VEKOP-16-2017-00005). The Project is supported by the European Structural and Investment Funds (grant agreement no. VEKOP-2.3.3-15-2017-00022). This research was supported by the Ministry for Innovation and Technology within the framework of the Higher Education Institutional Excellence Program (NKFIH-1159-6/2019) in the scope of plant breeding and plant protection researches of Szent István University.

\section{REFERENCE}

Al-Juhaimi, F., Ghafoor, K., and Babiker, E. E. (2012). Effect of gum Arabic edible coating on weight loss, firmness and sensory characteristics of cucumber (Cucumis sativus L.) fruit during storage. Pakistan Journal of Botany, 44(4): 1439-1444.

Ali, A., Maqbool, M., Ramachandran, S., and Alderson, P. G. (2010). Gum Arabic as a novel edible coating for enhancing shelf-life and improving postharvest quality of tomato (Solanum lycopersicum L.) fruit. Postharvest Biology and Technology, 58(1): 42-47.

Baranyai, L., Nguyen, L. L. P., Sao Dam, M., Zsom, T., and Hitka, G. (2020). Evaluation of precooling temperature and 1-MCP treatment on quality of 'Golden Delicious' apple. Journal of Applied Botany and Food Quality, 93: 130-135.

Bron, I. U., Ribeiro, R. V., Azzolini, M., Jacomino, A. P., and Machado, E. C. (2004). Chlorophyll fluorescence as a tool to evaluate the ripening of 'Golden' papaya fruit. Postharvest Biology and Technology, 33(2): 163-173.

Crisosto, C., Retzlaff, W., William, L., DeJong, T., and Zoffoli, J. (1993). Postharvest performance evaluation of plum (Prunus salicina Lindel. 'Casselman') fruit grown under three ozone concentrations. Journal of the American Society for Horticultural Science, 118(4): 497-502.

Guzel-Seydim, Z. B., Greene, A. K., and Seydim, A. C. (2004). Use of ozone in the food industry. LWT Food Science and Technology, 37(4): 453-460.

Habibi Najafi, M. B., and Haddad Khodaparast, M. H. (2009). Efficacy of ozone to reduce microbial populations in date fruits. Food Control, 20(1): 27-30.

Liu, W. (2014). Effect of different temperatures and parameters analysis of the storage life of fresh cucumber and tomato using controlled atmosphere technology. American Journal of Food Technology, 9(2): 117-126. 
Nguyen, L. P. L., Horváth, V., Dam, M. S., Hitka, G., Zsom, T., and Kókai, Z. (2018). Effect of 1-MCP, ethylene absorber and ozone on melon quality during storage. Progress in Agricultural Engineering Sciences, 14(s1): 101-110.

Nguyen, L. P. L., Visy, A., Baranyai, L., Friedrich, L., and Mahajan, P. V. (2020a). Application of hue spectra fingerprinting during cold storage and shelf-life of packaged sweet cherry. Journal of Food Measurement and Characterization, 14: 2689-2702.

Nguyen, L. P. L., Zsom, T., Sao Dam, M., Baranyai, L., and Hitka, G. (2020b). Comparison of 1-MCP treatment on four melon cultivars using different temperatures. Journal of Applied Botany and Food Quality, 93: 122-129.

Palou, L. S., Crisosto, C. H., Smilanick, J. L., Adaskaveg, J. E., and Zoffoli, J. P. (2002). Effects of continuous $0.3 \mathrm{ppm}$ ozone exposure on decay development and physiological responses of peaches and table grapes in cold storage. Postharvest Biology and Technology, 24(1): 39-48.

Skog, and CL Chu, L. (2001). Effect of ozone on qualities of fruits and vegetables in cold storage. Canadian Journal of Plant Science, 81(4): 773-778.

Watkins, C. B., and Nock, J. F. (2012). Production guide for storage of organic fruits and vegetables, pp. 5-9.

Zhang, Y., Zhang, M., and Yang, H. (2015). Postharvest chitosan-g-salicylic acid application alleviates chilling injury and preserves cucumber fruit quality during cold storage. Food chemistry, 174: 558-563.

Zsom, T., Zsom-Muha, V., Le Nguyen, L. P., Nagy, D., Hitka, G., Polgári, P., and Baranyai, L. (2020). Nondestructive detection of low temperature induced stress on postharvest quality of kápia type sweet pepper. Progress in Agricultural Engineering Sciences.

Open Access. This is an open-access article distributed under the terms of the Creative Commons Attribution 4.0 International License (https://creativecommons.org/licenses/by/4.0/), which permits unrestricted use, distribution, and reproduction in any medium, provided the original author and source are credited, a link to the CC License is provided, and changes - if any - are indicated. (SID_1) 